\title{
Review
}

\section{Beyond Discretionary Justice}

\author{
J. Skelly Wright*
}

Discretionary Justice: A Preliminary Inquiry. By Kenneth Culp Davis. Baton Rouge: Louisiana State Universily Press, 1969. Pp. xii, 233. $\$ 8.50$ (clothbound), $\$ 2.45$ (paperback, Universily of Illinois Press, 1971).

In his little book The Morality of Law, Lon Fuller relates an allegory about a King Rex who sets out to reform the legal system of his kingdom. Upon assuming the throne, King Rex repeals all existing law and, lacking the confidence to write a new code, begins the process of developing new rules on a case-by-case basis.

In this way under the stimulus of a variety of cases he hoped that his latent powers of generalization might develop and, proceeding case by case, he would gradually work out a system of rules that could be incorporated in a code. Unfortunately the defects in his education were more deep-seated than he had supposed. The venture failed completely. After he had handed down literally hundreds of decisions neither he nor his subjects could detect in those decisions any pattern whatsoever. Such tentatives toward generalization as were to be found in his opinions only compounded the confusion, for they gave false leads to his subjects and threw his own meager powers of judgment off balance in the decision of later cases. ${ }^{1}$

In the allegory, King Rex eventually dies, "old before his time and deeply disillusioned with his subjects." 2 In the real world, the King is still with us, enthroned in the legal department of a federal regulatory agency.

But although the King may feel secure for the present, his subjects are getting restless. Consumer groups are no longer so certain that

- Circuit Judge, United States Court of Appeals, District of Columbia Circuit. Ph.B. 1931; J.D. 1934, Loyola University (New Orlcans).

1. L. Fuller, THE MORALITY OF Lawy 34 (rev. ed. 1969) [hereinafter cited as Fullen].

2. Id. at 38 . 
the Federal Trade Commission acts in the public interest when it grants and denies secret merger clearances according to no ascertainable standards. Welfare mothers are beginning to wonder about the life and death power which a single social worker wields over them without any realistic possibility of restraint or review. Poor people no longer believe that something about the natural order makes it inevitable that the criminal laws be enforced against them, but not against white collar criminals who daily victimize them. There is the smell of revolution in the air.

Now Professor Davis, in his powerful manifesto Discretionary Justice, ${ }^{3}$ has proposed that we modify King Rex's powers, turning him into a constitutional monarch. Davis argues that the administrative system in this country is shot through with unnecessary discretion. The police, prosecutors, and petty bureaucrats in our local and national governments are free to run loose in an Alice-in-Wonderland of unchannelled, unreviewable, untrammelled discretion. The result, unsurprisingly, is a crazy quilt of secret, ad hoc decisions which are essentially lawless, because they are presently beyond the power of law to control. Professor Davis has the temerity to suggest that this is an intolerable situation in a country theoretically dedicated to equal justice under law. He then proceeds to provide a series of specific suggestions for how administrative discretion can be checked or channelled and made subject to binding, prospective rules. This is not to say that he argues for complete elimination of discretionary decisionmaking. He would not exchange Lewis Carroll's fantasy for Franz Kafka's nightmare. A tyranny of petty bureaucrats who lack power to change the rules even an iota in order to do justice is at least as bad as a tyranny of petty bureaucrats who make up the rules as they go along.

But the need for some discretion in no way justifies the vast scope of unnecessary discretionary authority which is harbored in our present administrative apparatus. While an agency is new and unfamiliax with the subject matter with which it is dealing, it may have to feel its way around for a while on a case-by-case basis. But from the very beginning, the agency should concentrate considerable attention on

3. K. Davis, Discretionary Justice-A Preliminary InQuiry (1969) (paper cd. 1971) [hereinafter cited to page number only]. 
the problem of developing coherent general principles to guide its decisions. As soon as such principles can be formulated, they should be publicly discussed and, if found satisfactory, set down in the form of binding rules. If the agency is still too uncertain to issue a complete set of rules, it should promulgate them for areas which have become well settled. If general rules to cover all cases are impossible, specific rules to cover identifiable sub-categories of cases should be issued. If the agency feels unable to do even this much, then it should be compelled to explain publicly the reasons for its inability to formulate prospective rules in a specific class of cases, and it should utilize other devices such as fair informal procedures, effective review by superior officers, and nonbinding policy statements to ensure that individual decisions are not arbitrary and capricious. The underlying tone of Discretionary Justice is optimistic: although there may be a hard core of decisionmaking which must remain discretionary, there is nothing intractable about most of the problem. If we have the will to create an effective system of law to guide and channel administrative decisionmaking, then the monster can be tamed.

II

The real question, of course, is whether we have the will. Professor Davis subtitles his book "A Preliminary Inquiry," and that caveat should be taken seriously. Davis has brilliantly and systematically laid bare the soft underbelly of the American legal system. Moreover, he has tentatively outlined means by which the most important abuses of discretionary power can be curbed. $\mathrm{He}$ is at his most convincing when he argues that "the procedure of administrative rule-making is ... one of the greatest inventions of modern government," 4 and his solution follows plainly: "the chief hope for confining discretionary power ... [lies] . . . in much more extensive administrative rulemaking." 5 An interlocking network of rules, laid out in advance, can serve as a bulwark which strengthens the agency and prevents cooptation by the forces which it is attempting to regulate. The absence of rules has too often meant that the agency is at the mercy of the pressures brought to bear on it, its decisions little more than the resulting vector produced by conflicting political and economic forces. ${ }^{\circ}$

4. P. 65.

5. P. 55.

6. See Shapiro, The Choice of Rulemaking or Adjudication in the Development of Administrative Policy, 78 HARv. L. REv. 921, 952 (1965). 
But while Professor Davis' perception of the problem is clear, when it comes to outlining methods by which agencies can be forced to make rules and to obey the rules they do make, he barely scratches the surface. This is a shortcoming which leaves Davis' work seriously flawed. He seems to suppose that many agencies will suddenly see the error of their ways. In his view, "the chief hope for con. fining discretionary power" lies in voluntary agency rule-making. If that is true, there may be no hope at all. For the sad fact is that powerful forces are at work which incline agencies toward an ad hoc, case-by-case mode of operation. The first of these is simply the bureaucratic imperative of keeping the wheels turning. As Professor Jaffe has written,

[t]ime has corrected one dearly held illusion. It was thought in the heyday of the New Deal that an operating administrative agency, because of its continuous exposure to the problems of an area, was ideally fitted for progressive planning and programming. We have found that such is not the case. The agency is so deeply, so anxiously involved in solving the problems of the moment that most of its effort goes out in keeping astride of its operating agenda. Furthermore, buffeted by strong, opposing forces, it looks for compromise, expediency, and short-term solutions. After its first strenuous years of conflict with those whom it must regulate, it may arrive at a modus vivendi which it looks upon and pronounces to be good. ${ }^{7}$

Once this accommodation is reached, the agency is sheltered from the scrutiny of Congress, the courts, and the public. It seems clear that the amorphous, ad hoc mode in which most agencies operate has made them resistant to congressional control. Of course, some agencies are notoriously vulnerable to a well-timed telephone call from a congressman or a threat from a powerful committee chairman. But these are essentially ad hoc devices to deal with ad hoc decisions. Most of the time they reflect the sort of constituent pressure from private interest groups which has too much effect on agency decisions alrendy. ${ }^{8}$ In the aggregate, all of the individual calls from congressmen and threats at appropriations time do not add up to systematic congres-

7. L. Jaffe, Judicial Control of Administrative Action 51 (1965).

8. The late Senator Dirksen's intervention in administrative affairs for the benefit of individual constituents, and his vociferous defense of this practice, are notorious. He once remarked, "I have been calling agencies for 25 years. . . . Are we to be put on the carpet because we represent our constituents, make inquiries, and find out what the status of matters is, and so serve our constituents?" 105 CoNG. RE. 14057 (1959). 
sional control at the policy level. The ineluctable fact is that all too often there can be no congressional supervision of agency policy because the agency has no policy to supervise. Congress will never be able to influence the directions in which agencies are heading until the agencies begin to head in some direction and stop floundering in the morass of case-by-case litigation.

Moreover, ad hoc decisions tend to leave the agency freer to change direction at will and allow it to avoid the risks inherent in advance commitments. ${ }^{9}$ As Professor Shapiro has pointed out, a reviewing court which might declare invalid a clearly promulgated regulation may well affirm the application in a particular case of a principle of adjudication based on past agency decisions. ${ }^{10}$ In addition, an agency will be more readily permitted to ignore its past principles of adjudication than to depart from its regulations. 11

Given this historical and legal context, it is unrealistic to suppose that many agencies will dramatically move to confine their own discretion. Fortunately, however, there are other strategies available to implement Professor Davis' plans for administrative reform of executive agencies. The publication of Discrelionary Justice coincides with the culmination of a number of trends in American thoughttrends which can be utilized to make the Davis solution something more than an unrealizable ideal. On the one hand, there has been a growing sense of disillusion with the role which regulatory agencies play in the political and economic processes of the country. Credit for the genesis of these critiques must go to conservative economic theoreticians who yearn for a return to a free market economy and view administrative intervention as officious intermeddling.12 But the sense of disillusion has spread throughout the political spectrum, and critics from the right and left now generally agree that many regulatory agencies are inept, inefficient, and overly protective of the interests which they are supposed to regulate. ${ }^{13}$

9. There may also be something to Professor Jaffe's observations: "The question may be asked whether there is not an essential conflict of attitude between the task of adjudication and long-range planning. The former may be thought to intensify the sense of the particular to a degree which makes planning appear inexact, insensitive, Utopian, and futile." JAFFE, supra note 7, at 20.

10. Shapiro, supra note 6 , at $944-47$.

11. Id. at 947-52.

12. See, e.g., M. Friedman, Captralism and Freedom 119.60 (1962).

13. See, e.g., Moss v. CAB, 430 F.2d 89I, 893 (D.C. Cir. 1970); F. Cox, R. Feulustu, \& J. SCHULZ, "THE NADER REPORT" ON THE FEDERAL TRADE CoMmaissios (1969); Mejers, The Root of the FTC's Confusion, in Public Policies and TIIER Polmics 104.09 (R. Ripley ed. 1966). 
On the other hand, we have seen in the last few years a dramatic, if still incipient, reassertion of congressional power which poses the first serious challenge to the practical supremacy of the executive branch since the early days of the New Deal. This movement began with congressional frustration over the inability of the legislature to affect the conduct of the Vietnam war. It has quickly spilled over, however, into numerous other areas. The right of the executive to impound appropriated funds and to impose sweeping wage-price controls without congressional guidance has recently come under challenge. More and more legislators have come to realize that the socalled "expertise" of the executive branch is in reality no more than a cloak which hides the raw exercise of untrammelled power. Whereas once it was believed that administrative "experts" could magically provide a "scientific" solution to public policy problems, ${ }^{14}$ many congressmen now realize that most questions of policy are questions of values, and that the people must determine for themselves the values which they favor. In time, the movement for greater balance between the legislature and the executive promises to bring about the first substantial reallocation of power in almost two generations.

\section{III}

It is possible that these overlapping movements toward a reassertion of congressional power and away from blind trust in administrative competence will, of their own force, produce voluntary reform. Indeed, there is some evidence that a few agencies-notably the Federal Trade Commission ${ }^{15}$-are already responding to public pressures and changing their ways. But for the reasons outlined above, I think it would be foolish to rely too heavily on voluntary conversion. Fortunately, such reliance is unnecessary. A side effect of the trends toward congressional power and distrust of administrative activity has been the discovery of a counter-tradition which favors close supervision of administrative agencies. This counter-tradition-long overshadowed by the mainstream infatuation with administrative expertise-is sup. ported by a number of legal doctrines which could serve to force reluctant administrators to conform their actions to prospective, publicly promulgated rules and standards.

14. See J. Landis, The Administrative Process 9.12 (1938) [hercinafter cited as LANDIS].

15. See Osborne, The Nixon Watch: Reform at the FTC, THE NEw Repunuc, Oct. 2, 1971, at 13-15; Osborne, The Nixon Watch: Reform at the FTC_LI, Oct, 16, 1971, at
10-11. 
The reform of administrative procedure is a large task, and Congress, the agencies, and the courts all have roles to play. Congress should control discretion by reassuming its rightful role as the architect of fundamental administrative policy. Its current discontent with the consequences of excessive delegation could best be translated into a practice of approving only those statutes which set standards sufficiently precise to ensure that the relevant agency receives clear signals regarding the policy it is expected to carry out. Congressional insistence on such clarity would also give the courts a workable standard for review, and-of great importance-enable congressmen to monitor more effectively the performance of executive agencies. Administrators should take their cue from Congress and the courts and move to confine their own discretion. The courts should control discretion by vigorously reasserting their inherent role as the interpreters of legislative enactments and guardians against invidious and irrational exercises of governmental power. They must repudiate the dictum of Gray v. Powell, which still seems to satisfy the Supreme Court: "Where, as here, a determination has been left to an administrative body, this delegation will be respected and the administrative conclusion left untouched."16 This attitude has led to the practice of sustaining any order of an agency which colorably has kept within the bounds of the statute ${ }^{17}$-an unjustifiable abdication of the responsibility of judicial review.

But while all branches of government must join in the fight to limit discretion, I believe it is the courts which will have to bear the primary burden. Not only must the courts, on occasion, formulate rules of their own which will limit discretion. They must also resuscitate the legal principles which will force sometimes reluctant congressmen and administrators to take action. The courts cannot bear the burden alone; they are not equipped to act as super-administrators, formulating individual rules to govern the thousands of cases heard daily by agencies. But they can reestablish the doctrines which were

16. 314 U.S. 402,412 (1941).

17. See, e.g., Brooks v. NLRB, 348 U.S. 96 (1954): NLRB v. Seven-Up Bottling Co. of Miami, Inc., 344 U.S. 344 (1953); NLRB v. Gullett Gin Co., 310 U.S. 361 (1951); FCC v. WOKO, Inc, 329 U.S. 223 (1946); Republic Aviation Corp. v. NLRB, 324 US. 793 (1945); SEC v. Chenery Corp., 318 U.S. 80 (1913). Of course, there is also a counter-tradition that favors active judicial review of agency decisionmaking. Sec, e.g., Burlington Truck Lines v. United States, 371 U.S. 156, 167 (1962); Secretary of Agriculture v. United States, 347 U.S. 645, 653 (1954); Ohio Bell Tel. Co. v. Public Utilities Comm'n, 301 U.S. 292 (1937). In fact, it is the thesis of this piece that this counter-tradition can be used to build an effective system of constraints against administrative arbitrariness. The only point I wish to make here is that in recent years the requirements of administrative consistency and rationality, while not abandoned, have been frequently observed in the breach. 
designed to compel or encourage other branches of government to assume their parts of the task. Some of these doctrines are outlined below.

\section{A. The Congressional Role: The Delegation Doctrine}

It is a commonplace that, in its entire history, the Supreme Court has invalidated only two statutes on the ground of improper delegation of power. ${ }^{18}$ Today, most scholars rank the delegation doctrine together with substantive due process, nullification, and common law forms of action as arcane notions which inexplicably fascinated an earlier generation but which were given the decent burials they deserved long ago. Indeed, even Professor Davis rejects the delegation doctrine as a realistic means of subjecting agencies to the rule of law. "What Congress says in some such statutes is, in effect: 'We the Congress don't know what the problems are: find them and deal with them.' In many circumstances this is sound government. And the determination of whether or when it is sound government is primarily for Congress to decide." 10

Yet, at the risk of seeming antiquarian, I think the reported demise of the delegation doctrine is a bit premature. To be sure, we can all join in rejecting broad formulations of the doctrine, such as the famous statement in Field v. Clark: "That Congress cannot delegate legislative power to the President is a principle universally recognized as vital to the integrity and maintenance of the system of government ordained by the Constitution."20 But one can reject this extreme position without conceding that Congress should be permitted, in effect, to vote itself out of business. There must be some limit on the extent to which Congress can transfer its own powers to other bodies without guidance as to how these powers should be exercised.

No judge of any federal court has specifically disavowed the delegation doctrine in its entirety, ${ }^{21}$ and numerous decisions can be cited

18. Panama Refining Co. v. Ryan, 293 U.S. 388 (1935); A. L. A. Schechter Poultry Corp. v. United States, 295 U.S. 495 (1935). See also Carter v. Carter Coal Co., 298 U.S. 238 (1936).

19. P. 48.

20. 143 U.S. 649, 692 (1892). See also United States v. Shreveport Grain \& Elcvator Co., 287 U.S. 77,85 (1932).

21. Even Professor Davis, while correcty arguing that de facto standardless delcgations have been permitted, concedes that "[ $t$ ] he courts keep repeating and repeating thit the exercise of delegated power must be guided by meaningful safeguards cven when the delegated power is carefully circumseribed and even when the intent to delegate is based upon a fully-considered judgment that the delegation is necessary and desirable . . .." K. Davis, Administrative Law Treatise 50 (1970 Supp.). 
which reaffirm it as at least a theoretical check on standardless shifts of power. ${ }^{22}$ As recently as 1963, three Supreme Court Justices found that

[t] he delegation of ... unrestrained authority to an executive official raises, to say the least, the gravest constitutional doubts. ... The principle that authority granted by the legislature must be limited by adequate standards serves two primary functions vital to preserving the separation of powers required by the Constitution. First, it insures that the fundamental policy decisions of our society will not be made by an appointed official but by the body immediately responsible to the people. Second, it prevents judicial review from becoming merely an exercise at large by providing the courts with some measure against which to judge the official action that has been challenged. ${ }^{23}$

In 1967, a fourth Justice argued: "Because the statute contains no meaningful standard by which the Secretary is to govern his designations, and no procedures to contest or review his designations, [it] is constitutionally insufficient to mark 'the field within which the [Secretary] is to act so that it may be known whether he has kept within it in compliance with the legislative will." "24

Moreover, the delegation doctrine continues to be applied-albeit in somewhat erratic fashion-by numerous state courts,, 25 and it has even proved a useful tool in some special situations in recent federal cases. ${ }^{26}$ I think the delegation doctrine retains an important potential as a check on the exercise of unbounded, standardless discretion by administrative agencies. At its core, the doctrine is based on the notion that agency action must occur within the context of a rule of law previously formulated by a legislative body. That concept is as im-

22. See, e.g., Arizona v. California, 373 U.S. 546, 585, 593 (1963): Lichter v. United States, 394 U.S. 742 (1948); Woods v. Cloyd W. Mfiller Co., 333 U.S. 138 (1948); Yakus v. United States, 321 U.S. 414 (1941).

23. Arizona v. California, 373 U.S. 546, 626 (1963) (Harlan, J., with Stcrart and Douglas, JJ., dissenting) (citations and footnotes omitted: original emphasis).

24. United States v. Robel 389 U.S. 258, 272-73 (1967) (Brennan, J., concurring), quoting from Yakus v. United States, 321 U.S. 414,425 (1944). It must be conceded that Mr. Justice Brennan would apparently restrict his application of the delegation doctrine to cases where protected freedoms and criminal sanctions are involved. See 359 U.S. at 276.

25. See, e.g., City of Chicago v. Pennsylvania R. R., 41 Ill.2d 245, 242 N.E.2d 152 (1968); Bologno v. O'Connell, 7 N.Y.2d 155, 164 N.E.2d 389, 196 N.Y.S.2d 90 (1959). But see, e.g., Kugler v. Yocum, 69 Cal.2d 371, 445 P.2d 303, 71 Cal. Rptr. 687 (1968); Warren v. Marion County, 222 Ore. 307, 313-14, 353 P.2d 257, 261 (1960).

26. Thus, on occasion, the Supreme Court has been willing to imply a standard in order to save the statute from an unconstitutionally broad delegation. See, e.g., Kent v. Dulles, 357 U.S. 116 (1958). Cf. Shuttesworth v. Birmingham, 394 U.S. 147 (1969); Sehneider v. Smith, 390 U.S. 17 (1968). 
portant now as it was a century and a half ago when it was first propounded.27

In the end, Professor Davis rejects the delegation doctrine as a means of controlling administrative discretion because, in his view, it is impractical. He reads the long history of the doctrine as conclusively demonstrating that the legislature either cannot or will not impose meaningful standards on administrative discretion. "[T]he emphasis," he says, "should not be on legislative clarification of standards but on administrative clarification, because that is where the hope lies."28 Moreover, he contends, legislative standards might not be desirable even if the legislature could be persuaded to provide them. There are times, Davis argues, when the legislature does not really know what it wants or when political pressure makes it impossible for it to accomplish its objectives. In these situations, if the job is to be done at all, it will have to be done by an agency under a broad delegation of discretionary authority. ${ }^{20}$

It seems to me both of these arguments are open to serious question. When Davis complains that the delegation doctrine has not solved the problem of discretionary power, he is heaving boulders from the none-too-safe haven of a rather fragile glass house. Discretionary Justice would not have been written if agency rule-making-"where the hope lies"-had provided a solution. As argued above, ${ }^{30}$ there are substantial reasons why agencies are unlikely to be persuaded that they should make fuller use of their rule-making power. Congress, on the other hand, seems to be in a mood to reassert some of its long dormant prerogatives. There is every reason to believe that, with a slight nudge from the courts, Congress would eagerly reassume its rightful role as the author of meaningful organic charters for administrative agencies.

Davis is not quite so vulnerable when he argues that at times the congressional will may not be clear enough to permit formulation of a specific set of standards under which the agencies should operate. When Congress is too divided or uncertain to articulate policy, it is

27. I am thus in accord with Judge Friendly's view that "[w]e still live under a Constitution which provides that all legislative Powers herein granted shall be vested in a Congress of the United States, which shall consist of a Senate and House of Rep. resentatives'; even if a statute telling an agency 'Here is the problem: deal with it' bc deemed to comply with the letter of that command, it hardly does with the spirit." $H$. Friendix, The FEDERAL AdMinistrative Agencies 21.22 (1962).

28. P. 50 (original emphasis).

29. Pp. 46, 49. In this respect, Davis seems to be in agreement with some of the strong advocates of administrative discretion. See, e.g., LANDIs, supra note 14, at 51 .

30. See pp. 578-79 supra. 
no doubt easier to pass an organic statute with some vague language about the "public interest" which tells the agency, in effect, to get the job done. But while this observation is no doubt correct, it seems to me to argue for a vigorous reassertion of the delegation doctrine rather than against it. An argument for letting the experts decide when the people's representatives are uncertain or cannot agree is an argument for paternalism and against democracy. ${ }^{31}$ As Justice Brennan has argued,

[f]ormulation of policy is a legislature's primary responsibility, entrusted to it by the electorate, and to the extent Congress delegates authority under indefinite standards, this policy-making function is passed on to other agencies, often not answerable or responsive in the same degree to the people. ${ }^{32}$

The whole reason we have broadly based representative assemblies is to require some degree of public consensus before governmental action occurs. To be sure, we pay a price for awaiting such consensus. Sometimes desirable action is delayed or becomes impossible altogether because the representative organs of government are too fragmented or uncertain to formulate a coherent policy. But our experience with broad delegations such as the Tonkin Gulf Resolution makes clear that there is a price to be paid for congressional abnegation as well.

Ultimately, the arguments for broad delegation rest on the illusion that problems are solved by conflict avoidance. Congress, for one reason or another, cannot deal with a problem, so it passes some "soft" statutes which throw the mess into the lap of an administrative agency. Such a broad delegation can yield only two possible results, both of which are unfortunate. On the one hand, if the problem is really intractable, it is unlikely that the agency, with all its expertise, will do any better with it than Congress. Indeed, if there is political opposition to any contemplated action, the agency may actually be more vulnerable than Congress. ${ }^{33}$ In this situation, the agency is likely to act like King Rex_blundering along on a case-by-case basis without any discernible direction or purpose. Alternatively, it is possible that

31. " "[T]aking things out of politics" [means] taking things out of popular control. This is a frequent device of special-interest groups to effect the transfer of governmental power away from the large public to the special-interest small publics." J. Arpusny, Policy AND ADMinistration 162 (1949).

32. United States v. Robel, 389 U.S. 258, 276 (1967) (Brennan, J., concurring).

33. "Where Congress has not been able to formulate a consensus, we cannot expect the politically weaker agency to do much better." JAFEE, supra note 7 , at 25. 
the agency will be able to deal with the problem forcefully. It may be that the agency is sufficiently insulated from political pressure so that it can take action which would have been unavailable to Congress, or that Congress is badly split while the agency is united. ${ }^{34}$ In this situation, a strong agency will be able to formulate prospective rules, develop a clear sense of purpose, and minimize unnecessary discretion. But these goals will have been accomplished at the expense of demo. cratic decisionmaking. The putatively substantial portion of the electorate which opposes the agency action, or which is merely uncertain as to its wisdom, is likely to believe-and with some justification-that Congress has done through the back door what it could not accomplish in direct, democratic fashion..$^{35}$

We have recently seen enough evidence of what happens when a substantial number of people come to believe that major decisions have been made without their consent. If the social fabric is to survive, the politics of manipulation and delegation simply must be replaced by a politics of informed consent. It is perfectly natural for congressmen to attempt to avoid or delay substantial conflict by any device available, including broad delegations of power to the executive branch. But it is time we came to realize that in a democracy conflict over basic policy cannot be avoided and that when too long delayed it may, like Langston Hughes' dream deferred, explode.

None of this is to argue that a revitalized delegation doctrine is likely to emerge easily and completely. There are severe problems involved in the development of a coherent, principled, and meaningful

34. See LANDIS, supra note 14 , at 51-55.

35. It is ultimately impossible to talk sensibly about administrative law outside the framework of a theory of democratic government. Such a theory would determine how loud a voice the citizenry should have in various kinds of decisions. Using critcria derived therefrom, one could then go about labelling certain decisions as properly legislative, others as administrative, judicial, and so forth. I do not propose, even if I could do so, to put forth such a theory, for it would sweep far broader than this review refuires. But the core of the argument may be stated. I have argued elsewhere that the Constitu. tion deliberately places certain decisions-notably those affecting minority rightsoutside the domain of the majority and its elected representatives. Wright, Professor Bickel, the Scholarly Tradition, and the Supreme Court, 84 HARv. L. Rev. 769, 787.88 (1971). Precisely because of this restriction, it is all the more necessary that those matters reserved for majority decision be done through majoritarian process. It is in this sense that legislative decisions are democratic: unlike a judge, whose decisions purport to be "principled," a legislator may trade off a vote on one question for the support of a colleague on another issue of greater importance to his constituents; decisions are made by vote, with the winning side presumably representing a greater number of citizens. Most important, legislators are subject to electoral control. The justification for the very existence of a bureaucracy, whose members go about their jobs regardless of whio wields elective power, is that legislators simply lack the time and expertise to administer the laws they have made. Civil servants are supposed to give effect to the legislators decisions, not make those decisions for them. Thus their only legitimate policynaking role is the interstitial application of the always imperfectly defined Iegislative will. 
theory of delegation. Delegation is, after all, a matter of degree, and the amount of power which it is permissible to delegate to an agency varies with the problem involved. ${ }^{36}$ As Professor Davis points out, some decisions, by their very nature, are more subject to control by prospective rules and standards than others. It would be a fairly simple matter, for example, for Congress to specify with a great deal more precision what exactly it wishes the Federal Communications Commission to do in order to equalize access to the electronic media. Yet it is hard to imagine how Congress could go beyond the vaguest sort of standards to control ratemaking by the Interstate Commerce Commission. It will be necessary to do some systematic thinking about the degree to which various categories of problems are subject to prospective congressional control. We need, in short, some standards for when we should require standards. To be sure, the overall standard is clear enough: Congress should channel its delegations of power with prospective guidelines and standards to the greatest extent possible. But ironically, the courts may have to work out the precise contours of the requirement of prospective standards on an empirical, case-by-case basis, and this process is likely to be time-consuming. In the meantime, I am convinced that Congress can be persuaded to do a great deal more than it is doing now, as a matter of constitutional morality if not constitutional compulsion.

\section{B. The Administrative Role: $A$ Rule-making Requirement}

If the courts are able to formulate a coherent delegation requirement or if Congress proves willing to assume a more active supervisory role voluntarily, many of the problems of unnecessary discretion will be resolved. But this proposition should not be taken to derogate from Professor Davis' thesis. Even if Congress assumed its full responsibility and began writing meaningful organic charters for administrative agencies, those bodies would still have to be given substantial power

36. I am thus in basic agreement with Dean Landis when he says: "Generalization as to the allowable limits of administrative discretion is dangerous, for the field is particularly one where differences in degree become differences in substance. It is possible to say, on the one hand, that the responsibility for fashioning a policy, not only of great economic importance but also one that has divided the faith and loyalty of clases of people, cannot appropriately be intrusted to the administrative; on the other, that the scope of administrative power should not be so narrowly defined as to take away from the administrative its capacity to achieve effectively the purposes of its creation. Such corollaries, however, are meaningless in the abstract. It is problems alone that can give them content, but the content that they should possess must have reference to situations seen in the light of the weaknesses and strength of administrative responsibility." LANDIs, supra note 14 , at 55 . 
to resolve individual controversies. The problem, as Professor Davis correctly perceives it, is to force the agencies to exercise that power through purposeful and coherent prospective rules rather than in the random, ad hoc, and secret manner in which they all too frequently operate at present. Once again, it seems to me the legal tools which could be utilized to reach this goal have already been fashioned. All we need do is bring those tools to bear on the problem in a forceful and determined manner.

Chief among these tools is the due process clause of the Constitution. It should be obvious that to have due process of law it is necessary for the decision involyed to be subject to law. Yet when we say a decision is ad hoc, random, or unreviewable we mean in effect the decision is lawless. As Professor Fuller has stated with admirable directness: "The first desideratum of a system for subjecting human conduct to the governance of rules is an obvious one: there must be rules." 37

It is time, then, we came to recognize that in at least some circumstances there is a due process right to have one's conduct governed by rules which are stated in advance. ${ }^{38}$ Moreover, these rules must be clearly formulated and publicly promulgated. These requirements have been recognized for centuries in the area of criminal law. No one would contend that a man could be arrested, tried, and convicted of a "crime" for acts which were perfectly legal at the time they were committed. ${ }^{30}$ Moreover, it has long been recognized that a criminal statute must be publicly promulgated and written precisely enough to give fair warning. ${ }^{40}$ Similarly, when noncriminal regulation borders on constitutionally protected conduct, the courts have repeatedly held that the statutes involved must be precisely drawn so as to make clenr what is lawful and what is not before the conduct in question takes place..$^{41}$

37. Fuller, supra note 1 , at 46 .

38. See, e.g., Holmes v. New York City Housing Authority, 398 F.2d 262 (2d Cir. 1968); Hornsby v. Allen, 326 F.2d 605 (5th Cir. 1964); United States v. Atkins, 323 F.2d 733, 742 (5th Cir. 1963). Cf. Landman v. Peyton, 370 F.2d 135, 139-41 (4th Cir.), cert. denied, 385 U.S. 881 (1966); Jackson v. Bishop, 268 F. Supp. 804, 815.16 (E.D. Ark. 1967), vacaled on other grounds, 404 F.2d 571 (8th Cir. 1968). See generally DAvis, supra note 21, at 58.62.

39. See, e.g., Burgess v. Salmon, 97 U.S. (7 Otto) 381 (1879); cf. Rosenberg v. United States, 346 U.S. 273, 290, reconsideration denied, 346 U.S. 324 (1953).

40. See, e.g., Connally v. General Const. Co., 269 U.S. 385, 391 (1926); Cline v. Frink Dairy Co., 274 U.S. 445, 465 (1927). See generally Note, The Void-For.Vagueness Doctrine in the Supreme Court, 109 U. PA. L. REv. 67 (1960).

41. See, e.g., Cantwell v. Connecticut, 310 U.S. 296 (1940); Schneider v. State, 308 U.S. 147 (1939); Hague v. CIO, 307 U.S. 496 (1939). See generally Note, The First Amendment Overbreadth Doctrine, 83 HaRv. L. REv. 844 (1970). 
As an abstract proposition, few would argue that these requirements are limited to the areas of criminal law and constitutional rights. Imagine, for example, a system where individual social workers are given the unfettered right to grant and deny welfare benefits to whomever they please on whatever basis they please. Or imagine a system under which a man's right to pursue his chosen occupation depends upon his ability to get approval from a board which gives no hint of when it will give such approval and when it will withhold it. Is it really open to question that such schemes would be unconstitutional? Regulatory systems which operate without rules are inherently irrational and arbitrary. The purpose of such a system is presumably to bring primary conduct into conformance with agreed upon societal norms. Yet a system operating without rules cannot possibly achieve this goal, since the people being regulated are not informed of what the societal norms are. Unless they are prescient, they cannot possibly be expected to mold their conduct in accordance with rules which, if they can be said to exist at all, are created after the conduct occurs. ${ }^{2}$

Moreover, it should be apparent that any system which operates without rules chills the exercise of constitutional rights. When a court strikes down a vaguely worded statute providing for licensing of public demonstrations, it presumably does so because the statute permits those charged with administering it to make decisions on the basis of criteria which are forbidden by the First Amendment. ${ }^{43}$ Yet precisely the same flaw is inherent in the statutory schemes described above. A social worker administering a standardless public assistance program might deny benefits because the applicant is a Black Panther. The medical board described above might withhold a license to an otherwise qualified physician because he belongs to the Republican Party. It might be argued that these possibilities do not in themselves make the schemes unconstitutional but rather only demonstrate that they are subject to abuse. When the individual abuses come to light, the argument goes, they will be corrected. But the trouble with a standardless regime is that the abuses may never come to light. In a system under which government officials do not have to act in accordance with publicly stated rules, it is very difficult to know when they are acting in accordance with secret, illicit rules.4t

\footnotetext{
42. See FuLIER, supra note 1 , at $46 \cdot 65$.

43. See Note, supra note 41 , at 857 .

44. The slaughter at Attica and the series of prison revolts which followed in its wake-notably at prisons in Norfolk and Walpole, Massachusetts and Rahway, New
} 
When these propositions are baldly stated, they seem obvious to the point of triteness. Yet the sad fact is that we have barely begun to apply these fundamental due process precepts to the millions of discretionary decisions made by government officials every day. Welfare workers $d o$ exist who possess the de facto power to grant or deny benefits as they choose. ${ }^{45}$ Government boards do control access to various professions without reference to any discernible criteria.46 Indeed, even in the area of criminal law, where the necessity for prospective rules is most widely recognized, police, prosecutors, judges, and parole officers continue to arrest and incarcerate people on the basis of standards which are apparent only to themselves. ${ }^{47}$ Under a criminal justice system which makes such conduct as petty gambling, possession of marijuana, statutory rape, and abortion criminal offenses, a large proportion of the population becomes criminal. When the law enforcement establishment picks and chooses on an ad hoc basis which of these "criminals" are to be arrested and prosecuted, they are in effect making up the criminal law as they go along, in a manner which suits the whims and prejudices of individual policemen and prosecutors. ${ }^{48}$ Similarly, when a judge decides to impose a maximum sentence or a parole board denies release without a statement of reasons, they make the degree of punishment subject to considerations which were not publicly explicated at the time the offense was committed. ${ }^{40}$

There is simply no reason why we should go on pretending this sort of ex post facto lawmaking by administrative fiat is constitutional. It cannot be doubted that most agencies possess the lawful authority to decide most of the cases which they in fact handle. But the fact that an agency is within the bounds of the relevant statutes in acting

Jersey-have focused public attention on the governance of prison institutions. In no area is the need for public ventilation and public rule-making more compelling. $\boldsymbol{A}$ few recent cases indicate that the courts are aware of this need. See Nolan $v$. Fitzpatrick, 451 F.2d 545 (lst Cir. 1971); Landman v. Royster, 333 F. Supp. 621 (E.D. Va. 1971); Smith v. Robbins, 328 F. Supp. 162 (D. Me. 1971); Landman v. Pcyton, 370 F.2d 195, 199.41 (4th Cir.), cert. denied, 385 U.S. 881 (1966); Jackson v. Bishop, 268 F. Supp. 804 (E.D. Ark. 1967), vacated on other grounds, 404 F.2d 571 (8th Cir. 1968).

45. Pp. 180-83. Discretionary Justice was written before the Supreme Court decided that welfare recipients were entitled, under the due process clause, to an cvidentiary hearing according them "rudimentary due process" before their benefits could be taken away. Goldberg v. Kelly, 397 U.S. 254, 267 (1970). But neither Goldberg nor any subse. quent decision does anything to check the abuses Professor Davis describes.

46. P. 38 .

47. For an argument that the police have a constitutional duty to formulate rules, see Amsterdam, The Supreme Court and the Rights of Suspects in Criminal Cases, 45 N.Y.U. L. Rev. 785, 813-15 (1970). Cf. United States v. Bryant, 439 F.2d 612 (D.C. Cir. 1971).

48. See Pp. 188-91.

49. See Pp. 126-41. 
has never been thought sufficient, by itself, to insulate its decision from judicial review. The decision must not only be lawful-it must be lawfully made as well.50 Indeed, that is what the due process clause is all about. As argued above, one element of a lawfully made decision is that it accords with previously stated and clearly articulated rules. Thus, in a proper circumstance, it is clearly within the power of a reviewing court to insist as a matter of constitutional law that the agency state prospective rules and standards before its decision will be enforced. ${ }^{51}$

Moreover, even if the reviewing court is not willing to go this far, there are several subconstitutional devices available to force administrative agencies into rule-making. In some circumstances, for example, it may be possible to extrapolate a rules requirement from the statute under which the agency operates. When Congress sets up an administrative agency, it provides guidelines which concern not only what decisions the agency is to make but also how those decisions are to be arrived at. True, Congress rarely states explicitly that the agency must act through rule-making rather than adjudication. But, as argued below, ${ }^{52}$ reviewing courts need not be reticent about putting meat on vague congressional language concerning the "what" of agency decisions. In proper circumstances, I believe, a court can construe congressional intent as to the "how" of these decisions as well. In a situation where an agency is capable of proceeding by rule-making rather than adjudication and where ad hoc decisionmaking is not a rational means of tackling the problem, a court would be justified in concluding that this mode of proceeding was not in accord with the purpose of the statute which the agency is administering. ${ }^{53}$ Indeed, given the strong constitutional considerations outlined above, ${ }^{54}$ such a conclusion fits neatly with the more general maxim that courts should construe congressional enactments so as to avoid serious constitutional question..$^{55}$

50. See, e.g., Ohio Bell Tel. Co. v. Public Utilities Comm'n, 301 U.S. 292 (1937); Londoner v. Denver, 210 U.S. 373 (1908); Folkways Broadcasting Co. v. FCC, 375 F2d 299 (D.C. Cir. 1967).

51. See note 47 supra.

52. See pp. 595.96 infra.

53. See Camp v. Herzog, 104 F. Supp. 134 (D.D.C. 1952), holding that, while the Labor Board had the power to disbar an attorney from practice, Congress did not intend for this power to be exercised on a case-by-case basis. Cf. NLRB v. Insurance Agents' Int'l Union, 361 U.S. 477 (1960), holding that Congress intended for the Board to determine the requirements of good faith bargaining on a case-by-case basis rather than by formulating per se rules.

54. See pp. 588.91 supra.

55. See, e.g., Welsh v. United States, 398 U.S. 333 (1970); Gutknecht v. United States, 396 U.S. 295 (1970); United States v. Rumely, 345 U.S. 4I, 45 (1953). 
Finally, even if the reviewing court rejects both the constitutional and the statutory theories for a rules requirement, there remain some situations in which the court can exercise its own inherent supervisory powers to force the agency to write rules governing its conduct. Thus if the police are destroying evidence, or preserving it, only in a random fashion, the courts can require police authorities to formulate rules governing the precise disposition of potential evidence in a variety of situations. ${ }^{50}$ Similarly, when an agency handles a recurring problem on an ad hoc basis despite the fact that a normative standard could easily be devised, courts can and should require rule-making on the basis of their inherent supervisory powers. ${ }^{57}$ These powers are derived from the underlying power of the courts to protect the integrity of judicial review. No one has ever questioned the authority of a court sitting in equity to issue orders designed to preserve a res which is sub judice. ${ }^{58} \mathrm{I}$ believe courts have a similar power to require analogous measures which make judicial review of agency action possible. Since it is obvious that judicial review cannot exist unless there is a standard against which agency action can be measured, the courts have the authority to demand that such a standard be erected. As Judge Bazelon has argued,

judicial review alone can correct only the most egregious abuses. ... When administrators provide a framework for principled decision-making, the result will be to diminish the importance of judicial review by enhancing the integrity of the administrative process, and to improve the quality of judicial review in those cases where judicial review is sought. ${ }^{50}$

It is clear, then, that when agencies refuse to make use of their rule-making powers, the courts need not take "no" for an answer. Under well established principles of law, the courts have the authority to demand that agency action be subject to rules. This is true because it is what the Constitution requires, because it is what Congress often intends, and because it is what the courts must do if they are to preserve their reviewing function. But, whatever theoretical pigecn. hole is chosen, it is ultimately true because fair procedures are impossible without rules which guide agency action. We cannot have a

56. See United States v. Bryant, 439 F.2d 642, 652 (D.C. Cir. 1971).

57. Cf. Environmental Defense Fund, Inc. v. Ruckelshaus, 439 F.2d 584 (D.C. Cir, 1971).

58. See, e.g., Continental Ill. Nat. Bank \& Trust Co. v. Chicago, Rock Island \& Pac. Ry., 294 U.S. 648 (1935); Kline v. Burke Const. Co., 260 U.S. 226 (1922).

59. Environmental Defense Fund, Inc. v. Ruckelshaus, 439 F.2d 584, 598 (D.C. Cir. 1971). 
society under law without first having laws. The judiciary fulfills its highest obligation when it insists not only that the laws be obeyed but also that there be laws to be obeyed.

\section{The Judicial Role: Review Without Rules}

Having said all this, I should hasten to add a caveat. I do not intend to adopt what Professor Davis has called the extravagant version of the rule of law. ${ }^{60}$ Advocates of discretionary decisionmaking can argue with some force that there is a value in flexible, empirical growth of the law and that the rules for resolving some problems are for one reason or another simply not susceptible to neat codifications.

My view is that these arguments are correct as far as they go, but that they are essentially incomplete. While I do not wish to dispute the proposition that in some situations comprehensive prospective rule-making is impossible or undesirable, I share Professor Davis' view that a great deal more can be done. The criminal justice system provides an excellent example. It is doubtless true that the decision to prosecute or not to prosecute a suspected offender is a complex one and it would be a mistake to require the determination to be made in accordance with totally inflexible rules. ${ }^{01}$ But this is not to say that prosecutorial discretion cannot be significantly narrowed without interfering with the sort of individualized justice that empirical decisionmaking is designed to protect. Studies of prosecutorial decisionmaking reveal that the decision to prosecute is based at least in part on a number of factors which are quite readily generalizable, such as the amount of evidence available and the likelihood of conviction. ${ }^{02}$ I see no reason why these relatively straightforward considerations cannot be stated in the form of prospective rules so that they can be judicially enforced and fairly applied.

Of course it is true that even after this has been done there will remain aspects of prosecutorial decisions which cannot be put in the form of binding, prospective rules. Some of these considerations will be too individual in nature to be generalized beyond the one case to which they apply. Others are more general in nature, but involve decisions as to allocation of prosecutorial resources which, if publicly

60. Pp. 28-33.

61. Cf. Goldstein, Police Discretion: The Ideal versus the Real, 23 Yun. AD. REv. 140 (1963). But see pp. 162-70.

62. See F. Miller, Prosecution-The Decision to Ciharge a Suspect witu a Crase 24-43 (1970). 
announced, might encourage criminal conduct.03 But the important point to be made is that, although in some situations it may be im. possible to formulate prospective rules governing official conduct, it does not follow that unbridled discretion should reign supreme. Although publicly announced prospective rules should be the preferred method of limiting agency discretion, there are other methods as well.

These alternative methods once again derive from basic notions about what courts are supposed to do in a constitutional democracy. One of their underlying functions is to ensure that official action is not irrational or invidious. The Administrative Procedure Act clearly empowers courts to set aside agency action which is "arbitrary, crpricious, an abuse of discretion, or otherwise not in accordance with law," ${ }^{4}$ or which is "contrary to constitutional right, power, privilege, or immunity." ${ }^{2}$ Thus even in situations where the agency cannot articulate a rule in advance, the courts should still oversee agency action to ensure that the agency is following some rational and permissible rule of decision. While it is sometimes inevitable that the rule of decision be developed on a case-by-case basis, this development should not be confused with a system under which decisions are made without rules. ${ }^{66}$ When the prosecutor chooses to press charges in one case but not in another, for example, he should be able to point to some distinction between the two cases which it is permissible for him to consider. While he may not be able to articulate in advance what all the distinguishing factors in all cases will be, he must at least be able to show later that cases treated differently were in fact different in some relevant respect-that is, that he is following some sort of rational, non-discriminatory rule. If he cannot make such a showing, his different treatment of the two cases is irrational or invidious, and hence violative of equal protection. ${ }^{07}$

Moreover, there are certain evidentiary principles which guard this

63. Cf. Shapiro, supra note 6 , at $928-29$.

64. 5 U.S.C. $\$ 706(2)(A)(1970)$.

65. 5 U.S.C. $\$ 706(2)(B)(1970)$. It is, of course, true that the Administrative procedure Act also precludes from review "agency action [which] is committed to agency discretion by law." 5 U.S.C. $\$ 701(a)(2)$ (1970). But in my view Congress should not be taken as having given agencies discretion to act in an arbitrary, irrational, or unconstitutional fashion. See Balanyi v. Local 1031, International Bhd. of Elec. Wkrs., 374 F.2d 723, 726 (7th Cir. 1967). Cf. Saferstein, Nonreviewability: A Functional Analysis of "Committed to Agency Discretion," 82 HARv. L. REV. 367, 370 (1968).

66. "It should . . . be emphasized . . . that the choice between rulemaking and adjudication is not necessarily the choice between the articulation of a rulc and an ad hoc approach in which each case is governed only by a general statutory provision. Agencies, like courts, frequently evolve detailed and precise rules in the course of adjudi. cation." Shapiro, supra note 6, at 926.

67. Cf., e.g., Morey v. Doud, 354 U.S. 457 (1957). 
requirement of rationality. For example, if the prosecutor has, over a period of time, been charging only blacks with certain crimes despite the fact that white violators are also brought to his attention, this means that his basis for prosecution, however stated, is inherently suspect $^{68}$ and that courts will scrutinize the reasons offered for the apparently invidious discrimination with particular care. 00

To be sure, none of these notions is particularly new or revolutionary. Indeed, they are the core concepts upon which equal protection doctrine is built. I offer them here only to demonstrate that methods are available to control agency discretion even in cases where prospective rule-making is impossible. Nor need these methods always involve constitutional adjudication. Even in situations where the agency is able to offer plausible reasons for distinguishing between different cases, it is still possible for the courts to limit the scope of agency choice. The administrative agencies, after all, derive all of their delegated power from statutes passed by the legislative body, and it is the task of the courts to interpret those statutes in cases which are properly brought before them.

Once again, the Administrative Procedure Act is quite explicit: "To the extent necessary to decision and when presented, the reviewing court shall decide all relevant questions of law, interpret constitutional and statutory provisions, and determine the meaning or applicability of the terms of an agency action." 70 If the agency acts beyond its statutory authority as the relevant statute is interpreted by the courts, the agency action must be reversed.71

The construction put on a statute by the agency charged with administering it is entitled to deference by the courts, and ordinarily that construction will be affirmed if it has a 'reasonable basis in law.' ... But the Courts are the final authorities on issues of statutory construction ... a and 'are not obliged to stand aside and rubber-stamp their affirmance of administrative decisions that they deem inconsistent with a statutory mandate or that frustrate the congressional policy underlying a statute.' ... 'The deference owed to an expert tribunal cannot be allowed to slip into a judicial inertia .... .72

68. Cf. Loving v. Virginia, 388 U.S. I (1967); MfcLaughlin v. Florida, 379 U.S. 184 (1964).

69. See, e.g., Yick Wo v. Hopkins, 118 U.S. 350 (1886).

70. 5 U.S.C. \& $706(1970)$.

71. See, e.g., Greater Boston Television Corp. v. FCC, 444 F.2d 811, 850.52 (D.C. Cir.). cert. denied, 403 U.S. 923 (1971); Mary Carter l'aint Co. v. FTC, 333 F.24 651 (juth Cir. 1964).

72. Volkswagenwerk Aktiengesellschaft v. FMC, 390 U.S. 261, 272 (1963), quoting from NLRB v. Hearst Publications, 322 U.S. 111, 131 (1944). See also NLRB v. Brown. 380 U.S. 278, 291 (1965); American Ship Building Co. v. NLRB, 380 U.S. 300,318 (1965). 
Of course many congressional delegations are phrased in extremely broad terms and, literally read, they permit an exceedingly wide range of agency choice. But the very breadth of such statutes provides an argument for a narrowing judicial construction in accordance with congressional intent. ${ }^{73}$ Advocates of administrative discretion seem to forget that the courts construe broad statutory mandates all the time - that indeed, the courts have no choice but to do so when faced with the problem of applying a vaguely worded statute to a specific set of facts. As Professor Jaffe has said,

[t] he scope of judicial review is ultimately conditioned and determined by the major proposition that the constitutional courts of this country are the acknowledged architects and guarantors of the integrity of the legal system.... An agency is not an island entire of itself. It is one of the many rooms in the magnificent mansion of the law. The very subordination of the agency to judicial jurisdiction is intended to proclaim the premise that each agency is to be brought into harmony with the totality of the law; the law as it is found in the statute at hand, the statute book at large, the principles and conceptions of the 'common law' and the ultimate guarantees associated with the Constitution. ${ }^{74}$

It may nonetheless be true that in situations where the agency sets out to limit and define its own mandate by adopting prospective rules to guide it in consideration of individual cases, the courts have some obligation to respect agency expertise. But when the agency has de. faulted-when it purports to do no more than follow the vague statutory mandate without additional prospective rules of its ownthe courts have no obligation to respect undemonstrated or hypothetical expertise. Instead, the reviewing court should look at the statute on its own and determine for itself whether the agency decision is within the congressional purpose. In this way, judges can narrow the scope of agency discretion even if the administrators are unwilling to narrow its scope themselves.

\section{IV}

Justice Jackson argued years ago that

administrative experience is of weight in judicial review only to this point-it is a persuasive reason for deference to the Commission in the exercise of its discretionary powers under and within

73. See Burlington Truck Lines v. United States, 371 U.S. 156, 166.68 (1962).

74. JAFFE, supra note 7, at 589-90. 
the law. It cannot be invoked to support action outside of the law. And what action is, and what is not, within the law must be determined by courts, when authorized to review, no matter how much deference is due to the agency's fact finding. Surely an administrative agency is not a law unto itself . . . .

Mr. Justice Jackson wrote those words in a dissenting opinion. His warning was not heeded in that case, and it has gone largely unheeded to the present day. Because of that neglect, we are now surrounded with agencies that are in fact laws unto themselves. The well-intentioned reformers of another generation have created a monster which threatens to destroy our very system of law.

And yet, although the danger is real, I cannot help sharing the underlying optimism of Professor Davis. Administrative discretion was created by law, and there is no inherent reason why the law should be unable to control it. The legal devices which we could use for this purpose were all formulated years ago and remain perfectly serviceable. Professor Davis and others have alerted us to the peril, and a broad public consensus is beginning to coalesce in favor of doing something about unbridled and arbitrary administrative power. If that consensus is properly marshalled and the legal tactics carefully planned, King Rex can indeed be turned into a constitutional monarch. Failing that, we may still be able to pull off a bloodless coup d'etat and send the King packing to a land that does not purport to govern its affairs by rules of law.

75. SEC v. Chenery Corp., 332 U.S. 194, 215 (1947) (Jackson, J., dissenting). 
